F. Reprod. Fert. (1970) 23, 341-343

\title{
OESTRUS AND INDUCED OVULATION IN THE MEADOW VOLE, MICROTUS PENNSYLVANICUS
}

\author{
F. V. GLULOW AND F. F. MALLORY \\ Department of Biology, Laurentian University, Sudbury, Ontario, Canada
}

(Received 19th May 1970)

\begin{abstract}
Summary. Forty female meadow voles (Microtus pennsylvanicus), bred from stock trapped in the wild, showed no regular cycles in their vaginal smear patterns. At autopsy, twenty virgin voles showed no evidence that spontaneous ovulations had occurred. Twenty recently mated females had fresh corpora lutea in their ovaries when killed. The conclusion was drawn that under laboratory conditions this species is an induced ovulator, coitus providing the stimulus for ovulation. A leucocytic invasion of a previously cornified or nucleated smear pattern is an indicator of ovulation in the meadow vole.
\end{abstract}

Vaginal smear patterns and studies of ovarian structure, before and after coitus, show the short-tailed field vole, Microtus agrestis (Austin, 1957; Chitty \& Austin, 1957; Clarke \& Kennedy, 1967; Breed, 1967, 1968), the prairie vole, M. ochrogaster (Richmond \& Conaway, 1969a, b), the Levant vole, $M$. guentheri (Bodenheimer \& Sulman, 1946) and the California vole, $M$. californicus (Greenwald, 1956) to be species which may have neither regular oestrous cycles nor spontaneous ovulations under laboratory conditions. Evidence has been presented that oestrous cycles and spontaneous ovulations may sometimes occur in M. agrestis (Chitty \& Austin, 1957; Chitty, 1957), the tundra vole, $M$. oeconomus (Hoyte, 1955) and the field vole, $M$. arvalis (Delost, 1955). Experiments on the meadow vole, $M$. pennsylvanicus, were performed to clarify the reproductive status of the species and are reported here.

Mature female voles, bred in this department from stock trapped in the wild, were used in the experiments. The animals were isolated at weaning (17 to 20 days of age) and were maintained throughout the experiment in small plastic cages $(28.5 \times 17.5 \times 12.5 \mathrm{~cm})$ with ample water, cotton-wool for bedding material, hay for cover, unrestricted oats and carrot twice a week for food. The cages were in a room with regulated temperature $\left(25 \pm 2^{\circ} \mathrm{C}\right)$ and lighting (18 hr light $/ 6 \mathrm{hr}$ dark).

Vaginal smears were taken by means of a wire loop from forty females, twice daily for 20 days. After staining the smears with a $1 \%$ aqueous solution of toluidene blue, the abundance of each of the three cell types present (cornified, nucleated and leucocytic) were scored on a 0 to 5 scale and recorded.

Twenty females were paired with males and left together for 3 days or more for the effects of copulation to be studied on the vaginal smear pattern and ovarian structure. Spermatozoa in a vaginal smear or a marked leucocytic invasion of a 
previously cornified or nucleated smear pattern was taken as evidence that copulation had occurred. These females were killed by cervical dislocation immediately after separating them from the males. Twenty virgin females, which had not been paired with males, were similarly killed.

The ovaries were dissected out, placed in Bouin's fixative, and subsequently weighed to $0.1 \mathrm{mg}$ on a torsion balance. The organs were microscopically examined for the presence of ovarian follicles and corpora lutea after being serially sectioned at $6 \mu$ and stained with haematoxylin and eosin.

The smear records of the forty females showed no regular cyclic changes in the abundance of the three cell types in the 20 days of observation. There was some variation: while thirty of the animals showed a predominance of cornified cells throughout the period, eight showed erratic invasions by leucocytes and two showed a constantly leucocytic smear, with few nucleated or cornified cells present, for the whole period. Nucleated cells, although seen in all smear records, were never the predominant type.

Of the twenty females placed with males, eighteen showed a leucocytic invasion within $72 \mathrm{hr}$ of pairing. The presence of spermatozoa was recorded in sixteen females.

The mean ovarian weight of the virgins was $5.5 \pm 0.5 \mathrm{mg}$ (range 1.5 to $10.0 \mathrm{mg}$ ); of the mated females, $9.5 \pm 0.6 \mathrm{mg}$ (range 3.2 to $12.9 \mathrm{mg}$ ). This difference was significant $(t=5.30 ; P<0.001)$. Ovaries from the virgins contained no corpora lutea but follicles in all stages of development were present. All of the twenty females which had been with males showed corpora lutea.

The data presented show that the isolated female voles kept under laboratory conditions gave no indication of spontaneous ovulations or of regular oestrous cycles in their vaginal smears. Coitus has been demonstrated to be a stimulus for ovulation.

Our results do not agree either with the observation of Asdell \& Hamilton (unpublished work cited in Asdell, 1964) that this species has a mouse- or ratlike smear pattern cycle or the inference drawn from this observation by Asdell (1964) that the species is a spontaneous ovulator. Lack of information makes it impossible to tell if the conditions under which the animals of Asdell \& Hamilton were kept were the same as for those in our experiments. It is possible that the suggestion that the field vole is either a spontaneous or induced ovulator depending on environmental factors (Chitty \& Austin, 1957), is applicable to the meadow vole. We did not investigate the possibility that $M$. pennsylvanicus shows a behavioural oestrus, as suggested for $M$. agrestis by Breed (1967), which is not reflected in vaginal smear patterns.

We concur with Breed's statement to the effect that only circumstantial evidence points to spontaneous ovulation in the genus Microtus and we question the validity of using only vaginal smears or behaviour to assess the reproductive status of small mammals, a doubt also expressed by Richmond \& Conaway (1969b).

$M$. pennsylvanicus joins $M$. agrestis, $M$. ochrogaster, $M$. guentheri and $M$. californicus as species which show unequivocal evidence of induced ovulation following coitus. We suggest that induced ovulation may be a general feature of the genus 
Microtus. The high adaptive value of induced ovulation for a species recovering from a low population density has been suggested by Greenwald (1956). Under such conditions, the chances of fertile matings should be high, even if the encounters between animals are infrequent.

We thank Mrs T. Kreke for technical assistance. This work was supported by Grant A-5070 from the National Research Council of Canada.

\section{REFERENCES}

Asdel. , S. A. (1964) Patterns of mammalian reproduction, 2nd edn. Cornell University Press, Ithaca.

Austin, G. R. (1957) Oestrus and ovulation in the field vole, (Microtus agrestis). F. Endocr. 15, iv.

Bonenhemer, F. S. \& Sulman, F. (1946) The oestrous cycle of Microtus guentheri D. and A., and its ecological implications. Ecology, 27, 253.

Breed, W. G. (1967) Ovulation in the genus Microtus. Nature, Lond. 214, 826.

BreEd, W. G. (1968) Oestrus and ovarian histology in the lactating vole (Microtus agrestis). 7 . Reprod. Fert. 18, 33.

Gнттту, H. (1957) The oestrous cycle and gestation period in the lactating field vole, Microtus agrestis. 7. Endocr. 15, 279.

Ghrтty, H. \& Austin, C. R. (1957) Environmental modification of oestrus in the vole. Nature, Lond. $179,592$.

Clarke, J. R. \& KENNEdy, J. P. (1967) Effect of light upon gonad activity in the vole (Microtus agrestis). Gen. E̊ compar. Endocr. 8, 474.

Delost, P. (1955) Etude de la biologie sexuelle du campagnol des champs (Microtus arvalis P.). Archs Anat. microsc. Morph. exp. 44, 150.

Greenwald, G. S. (1956) The reproductive cycle of the field mouse Microtus pennsylvanicus. 7. Mammal. $37,213$.

Hoyte, H. M. D. (1955) Observations on some small mammals of Arctic Norway. F. Anim. Ecol. $24,412$.

Richmond, M. \& Conaway, C. H. (1969a) Management, breeding, and reproductive performance of the vole, Microtus ochrogaster, in a laboratory colony. Lab. Anim. Care, 19, 80.

Richmond, M. \& Conaway, G. H. (1969b) Induced ovulation and oestrus in Microtus ochrogaster. $\mathcal{F}$. Reprod. Fert. Suppl. 6, 357. 